\title{
No hard feelings? Non-succeeding siblings and their perceptions of justice in family firms
}

\author{
Ilse Matser, Jelle Bouma and Erik Veldhuizen \\ Windesheim University of Applied Sciences, Zwolle, The Netherlands
}

\begin{abstract}
Purpose - Family farms, in which business and family life are intricately interwoven, offer an interesting context for better understanding the interdependence between the family and business system. Many family farms struggle to survive, and the succession process is a key period in which the low returns on investment become evident but also the emotional attachment of the family to the farm and the willingness to transfer the business to the next generation. We take the perspective of non-succeeding siblings since they are crucial for a successful succession but their role and position in this process is far from clear. This study will help to increase our knowledge of how fairness is perceived by non-successors and of the impact of perceived (in)justice on the family business system.

Design/methodology/approach - To analyze the effect on sibling relationships of an unequal outcome of the succession process, we choose the family farm context. We used interview data from multiple family members from several family farms in the Netherlands in different stages of succession. We utilized a framework based on justice theory to analyze perceptions of fairness among non-succeeding siblings. The central research question for this study is as follows: How do non-succeeding siblings perceive justice with regard to family firm succession?

Findings - The acceptance of the outcomes of the succession process by non-succeeding siblings is influenced by their perception of the fairness of the process itself and decisions made by the incumbent and successor with regard to these outcomes. It seems that stakeholders who occupy multiple roles with conflicting justice perspectives handle these contradictions with the help of an overarching goal-in this study, preserving the continuity of the family farm - and by prioritizing and adjusting the justice perspectives accordingly. The findings further show that both distributive justice and procedural justice are important and interact with each other.

Originality/value - Our study contributes to the literature by applying the theoretical framework of distributive and procedural justice to the context of family farm succession. This helps us to understand the position of non-succeeding siblings and their role and position in the succession process, which is important because sibling relationships have a significant impact on family harmony, with potential consequences for the business as well.
\end{abstract}

Keywords Family business, Communication, Family dynamics, Fairness, Succession planning, Family farms Paper type Research paper

\section{Introduction}

When the parents passed away years after their only son took over the farm it became clear that the inheritance for the non-succeeding sisters was only a fraction of the market value of the property. Influenced by her husband, one of the sisters demanded the portion allotted to her by Dutch law,

(C) Ilse Matser, Jelle Bouma and Erik Veldhuizen. Published by Emerald Publishing Limited. This article is published under the Creative Commons Attribution (CC BY 4.0) licence. Anyone may reproduce, distribute, translate and create derivative works of this article (for both commercial and non-commercial purposes), subject to full attribution to the original publication and authors. The full terms of this licence may be seen at http://creativecommons.org/licences/by/4.0/legalcode.

We would like to thank the Special Issue Editors and two anonymous reviewers for their very thoughtful and constructive suggestions on how to improve the manuscript.

Funding: This research was partly funded by a research grant provided by The Taskforce for Applied Research, which is part of the Netherlands Organisation for Scientific Research (NWO) and is financed by the Ministry of Education, Culture and Science.

Received 26 September 2018

Revised 1 February 2019 21 August 2019

14 November 2019

13 December 2019

Accepted 14 December 2019 
which was equal to about six times her inheritance otherwise. This led to a major dispute among the siblings. To meet his sister's demands, the brother would have to sell the farm. Eventually, the sister decided that she did not want this to happen, and she agreed to accept her inheritance as it was. Unfortunately, the relations between the siblings have been irreparably damaged (real-life story told anonymously)

Many family farms struggle to survive (Glover and Reay, 2015), and the succession process is an especially key period in which the low returns on investment become evident. In the Netherlands, for instance, the going-concern value of a farm is often lower than its current market value (Braaksma et al., 2012; Stokkers et al., 2010). Moreover, the continuity of a family farm can generally be ensured only by an unequal distribution of the property among the succeeding and non-succeeding children (Van der Meulen et al., 2014). Consequently, the nonsucceeding siblings have to face a very unequal wealth distribution (Cassidy and McGrath, 2014). In the Netherlands, non-succeeding siblings typically accept this unequal outcome, which is referred to as the "granting factor," meaning that non-succeeding siblings grant the farm to the successor and renounce their claim on any future inheritance (Beukema, 2017).

The negative financial consequences for non-successors in this context challenge the widely acknowledged idea that the long-term prosperity of a family business system depends upon positive outcomes in both the business and the family dimensions (e.g. Litz, 2008; Sharma, 2004; Ward, 1987). Moreover, although many studies in the family business literature focus on the impact of the family on the business, little is yet known about the impact of the business on the family's well-being (Litz et al., 2012; Yu et al.,2012). In this article, we focus on the perspectives of non-succeeding siblings who have to deal with unequal outcomes. This investigation is in line with family system theory, which underscores the significance of sibling relationships for understanding family dynamics and the total family system (Whiteman et al., 2011). The specificities of family farm succession (non-succeeding siblings granting the farm to the successor and accepting negative consequences for their own wealth) represent a perfect context in which to analyze the effect of unequal outcomes on sibling relationships and their impact on family harmony, with potential consequences for the businesses as well.

Consequently, we investigate the perception of the phenomenon of non-succeeding siblings in the context of family farms. Family farming can be viewed as an extreme case, with specificities such as strong emotional attachment to the farm, strong ties between family members, the combination of business and family residency, embedded traditional roles, property that is difficult to divide and low returns on investment and low net cash flows. As a consequence of these factors, the attitude and behavior of nonsucceeding siblings play a crucial role in successful intergenerational succession because if the siblings do not grant the farm to the successor, firm continuity is threatened. Since their role and position in the succession process is far from clear (Cassidy and McGrath, 2014), it seems vital to take the perspective of non-succeeding siblings into account to gain a better understanding of how families deal with the unequal distribution of wealth in a succession process (Taylor and Norris, 2000). We apply organizational and family justice perspectives (e.g. Adams, 1965; Colquitt et al., 2001; Leventhal, 1980) to address the following research question: How do nonsucceeding siblings perceive justice with regard to family firm succession?

Methodologically, we rely on case-study data on eight family farms in different stages of succession. In-depth examination of individual perceptions of justice is a key point in achieving our aim, because justice deals with a person's perceptions of "who" is entitled to "what" from "whom" in a particular situation (Lerner, 1980). Therefore, as a primary data source, we use interview data gathered from 12 non-succeeding siblings, their parents and the succeeding siblings. Based on our findings, we develop a conceptual framework that extends the family firm succession literature by applying justice principles (i.e. distributive and 
procedural justice) to the succession process to interpret the acceptance by the nonsucceeding siblings of the distribution of the inheritance.

Our article makes at least three contributions to the literature. First, we contribute to the family business literature by shedding new light on how fairness is perceived by nonsuccessors and how perceived (in)justice can affect the family system, with consequences for the balance between the family and the business (Cassidy and McGrath, 2014; Wallace et al., 1994). Second, focusing on non-succeeding siblings helps provide a more general and holistic picture of succession processes in family farms beyond the traditional emphasis on successor and incumbent. More research on family farm succession is necessary to unveil the idiosyncratic characteristics of family farms, which define a unique context for the familybusiness relationship, one which, in turn, provides useful insights for family business research in general (Suess-Reyes and Furtsch, 2016). Third, we also make an inverse contribution (Pérez Rodríguez and Basco, 2011) to the justice literature. Thus far, this stream of literature has rarely been applied in the family business field (with some exceptions, such as Ayres, 1990; Daspit et al., 2016; Van der Heyden et al., 2005). The family business context, in which conflict can arise because of the overlap between ownership, business and family, provides a unique setting for gaining a deeper understanding of how stakeholders with multiple roles, to which conflicting justice perspectives may apply, handle these contradictions. In the context of the family farm, we find that business continuity as a value for the family outweighs other justice principles and that this helps stakeholders to handle conflicting justice perspectives stemming from multiple roles.

Our article is structured as follows. The next section provides a short overview of the relevant literature on siblings and succession. It is followed by an introduction to the justice literature, which serves as the theoretical framework for this study. Next, the unique context of the family farm is introduced. In the method section, we describe the Dutch context, the research project, the data-collection process and our data analysis. The final sections present the findings, discussion and conclusions.

\section{Theoretical considerations: succession and siblings}

Since the start of academic research on family firms in the early 1980s, succession has been a leading topic in the family business literature (Gibb Dyer and Sanchez, 1998). The vast number of studies on family firm succession reflects the importance of successful transfer of management and ownership for achieving family firm continuity (Barach and Gantisky, 1995; Harvey and Evans, 1994; Sharma, 2004; Zellweger et al., 2012). The transfer of a family firm is a highly complex process with several phases (pre-succession, the event and postsuccession) and is strongly influenced by many factors stemming from the business (e.g. size, sector and profitability) and family (e.g. degree of harmony, age of family members and number of siblings) contexts (Le Breton-Milleret al., 2004). In general, the family business literature considers the succession process to be successful when the continuity of the business is secured and harmony within the family is maintained (e.g. Gilding et al., 2015; Sharma et al., 2004).

Although the importance of family harmony as an outcome of the succession process is widely acknowledged, less is known about how family harmony can be preserved. This is in line with the fact that most research in the family business field so far has focused on the business side and largely neglected the family side (Daspit et al., 2016) and as a consequence also overlooks the reciprocal influence of family on business and vice versa (Jennings et al., 2013). Furthermore, the studies that do draw attention to the importance of sustaining family harmony take the narrow perspective of the incumbent (e.g. Gilding et al., 2015; Richards et al., 2019) or the successor (Sharma and Irving, 2005; Garcia et al., 2019) and do not include other family members such as spouses or other siblings. Therefore, we turn our research effort 
toward the family and use insights from family science (Garcia et al., 2019; Jaskiewicz and Dyer, 2017) to gain a better understanding of the family side, focusing specifically on the role of non-succeeding siblings in the succession process.

Family system theory underscores the significance of sibling relationships for understanding family dynamics and the total family system (Whiteman et al., 2011). The majority of us have at least one sibling (for example, in the Netherlands, $63 \%$ of all family households have at least two children, CBS 2018), and sibling relationships are often the longest-lasting relationships in individual lives (Cicirelli, 1995). In the specific case of succession in family firms, the fact that one (or a few) of the siblings takes over the firm and the others do not can have a major impact on the sibling relationship and thus on family harmony. This choice of a successor from among siblings has received some attention in family business studies (e.g. Calabrò et al., 2018; Bennedsen et al., 2007). For instance, Calabrò et al. (2018) find a positive effect on post-succession firm performance when a second- or subsequent-born sibling is appointed. However, this study does not take into account the effects on family harmony of disregarding the rules of primogeniture.

In addition, sibling relationships were studied in the context of sibling partnerships, when brothers and/or sisters co-own and manage the family business together (Farrington et al., 2012; Friedman, 1991). The potential detrimental effects on the continuity of family firms of sibling rivalry within sibling partnerships have been acknowledged (Friedman, 1991; Kidwell et al., 2013). Extreme deviant behavior by one of the siblings in a family business due to perceived injustice is known as the "Fredo effect," after Fredo Corleone, the middle son in Puzo's novel and Coppola's film series The Godfather. The "Fredo effect" describes a family member's incompetence, opportunistic behavior and/or ethically dubious actions, which can impede the business's success and potentially result in a scandal that leads to the firm's demise (Kidwell et al., 2013). The root cause of Fredo's deviant behavior is his feeling of injustice about how he is treated in comparison to his brothers. We suspect that similar feelings can also arise, in a less extreme way, between successors and non-successors in the family domain. The positive or negative feelings non-succeeding siblings have about the outcomes of the succession process may have positive or negative effects on sibling relationships and, consequently, a positive or negative effect on family harmony. A key factor for explaining these positive or negative feelings is the perception by the non-succeeding sibling of justice in the succession process and its outcome. Therefore, we introduce the theory of justice as a lens with which to gain a better understanding of the position of nonsucceeding siblings in the succession process.

\section{Theory of justice}

The theory of social justice has been applied in many research fields, has been applied in the study of many domains, such as society, law, management and family, among others. (Cropanzano and Wright, 2001; Cropanzano et al., 2007). From a philosophical standpoint, the role of justice is to provide a way of assigning rights and duties in the basic institutions of society and to define the appropriate distribution of the benefits and burdens of social cooperation (Rawls, 1997). The concept of justice becomes relevant "whenever persons put forward conflicting claims to the division of social advantages under conditions of moderate scarcity" (Rawls, 1997, p. 110). Justice is described by Lerner (1980) as "an individual sense of fairness that is based on perceived entitlement in a particular situation." This well-known description reflects at the same time the common practice of using "justice" and "fairness" interchangeably (Samara and Paul, 2019). For our discussion, it is important to understand that justice and fairness are overlapping but distinct constructs. Whereas justice refers to whether one adheres to certain rules of conduct, fairness refers to an individual moral evaluation of this conduct (Goldman and Cropanzano, 2015). In this way, justice is a cause of fairness, and justice is more objective since it refers to accepted rules within a certain context, 
whereas fairness is more subjective because it refers to individuals' perception of these rules and the degree of compliance with these rules. To apply justice theory within the family business context, it is necessary to take into account that the family business is a social organization that is influenced by the family sphere as well as by the business and ownership sphere (Tagiuri and Davis, 1996). Therefore we first review the literature on justice in the family domain, then organizational justice and lastly justice in the family business context.

\section{Justice in the family domain}

The theme of adult sibling relationships falls within the arena of social psychology. Social psychology aims to explain how individuals influence each other by looking at, for example, group processes, social roles and social interaction dynamics (Whiteman et al., 2011). Social comparison theory (Festinger, 1954), social exchange theory (Kelley and Thibaut, 1978) and equity theory (Adams, 1965) are complementary perspectives that have been applied to describe and explain variations in sibling relationships and where perspectives of justice and fairness play a central role (Whiteman et al., 2011).

The equity theory of Adams (1965), building on the social comparison theory of Festinger, holds that individuals assess the fairness of a situation by using a set of proportional equations in which they measure their own inputs (e.g. education, intelligence and effort) relative to their own outcomes and compare the resulting ratio with that of a relevant other person (e.g. a colleague). Emotional distress, relationship dissatisfaction and efforts toward relationship change are the results of imbalances in partners' ratios of contributions to and rewards from their shared relationship (Whiteman et al., 2011). During adulthood, when the "voluntary" nature of the sibling relationship makes it possible for siblings to stay close to each other or to disconnect, equity theory is useful in explaining potential different viewpoints between siblings and the consequences on their relationships. A review by Whiteman (2011) reveals some studies on how siblings cooperate in caring for an elderly parent. In line with equity theory, studies (e.g. Ingersoll-Dayton et al., 2003) reveal that the primary caregiver applies a variety of behavioral as well as psychological strategies in order to reestablish equity and that when these efforts are unsuccessful it can lead to the dissolution of the sibling relationship. One study found that siblings stopped interacting or even initiated legal action against one another when the stress of caregiving became too intense (Strawbridge and Wallhagen, 1991).

Although Adams (1965) advocates the use of an equity rule, there are other principles for determining distributive justice. A different approach is human-needs-based allocation, in which decisions are based on the needs of the individual. Another basis for justice is equality, where the rule is that rewards should be divided equally among participants regardless of their individual contributions. Research has shown that the equality principle plays a prominent role in judging the fairness of reward allocation between siblings (Thomson and Jones, 2005), suggesting the likelihood that sibling relationships encourage the avoidance of favoritism. This mechanism is found in a study exploring how siblings experienced fairness in parental decisions about financial support for housing (Heath, 2018): in interviews, a majority of young adults expressed the expectation that their parents would treat the siblings equally in the provision of financial support for housing. Fairness was assumed, based on the assumption that parents pay a high price for not treating their children identically. Thus, based on the family system literature, it seems that the principle of equal treatment of siblings is a very powerful one in decisions regarding allocations between family members. In addition, there is attention to the human needs of family members, for example, when taking care of elderly parents, while the equity principle plays a role when siblings compare the effort each puts into the task of caring for their parents. 
Justice in business domain

Within the business domain, the theory of justice is applied under the label of "organizational justice." Organizational justice has proven to be a powerful construct for explaining individual behavior in the workplace. Research has shown that perceived organizational justice is positively related to aspects such as trust and commitment, helpful citizenship behavior and diminished conflict (Cropanzano and Wright, 2001; Cropanzano et al., 2007). On the other hand, feelings of injustice can lead to negative behaviors in organizations, including jealousy, retaliation, consumption and opportunism (Van der Heyden et al., 2005). Within organizations, the "rational" equity rule stands as a baseline argument: in principle, employees expect to be rewarded based on their contributions, so that the one who performs best receives a promotion or other rewards. However, depending on the culture of the organization and the specific context, equality- and need-based judgments have proved to add value as well (Cropanzano et al., 2007). For example treating personnel equally helps in creating team spirit and attention to the specific needs of colleagues aligns with what employees expect in terms of ethical behavior on the part of management.

In addition, within the organizational justice literature there has been attention to the relevance of distinguishing between distributive justice, which refers to the fairness of outcome distributions as discussed above and procedural justice, which refers to the fairness of the procedures used to determine the outcome distributions (Leventhal, 1980; Thibault and Walker, 1975). The seminal work of Thibault and Walker (1975) revealed the importance of taking the decision-making process into account when considering justice. They showed that actors involved in legal procedures viewed those procedures as fair when they felt they had process control (i.e. control over the presentation of their arguments and sufficient time to present their case). Furthermore, a fair process leads to intellectual and emotional recognition, which creates the commitment and trust that build voluntary cooperation in, for instance, the execution of strategic plans (Kim and Mauborgne, 1993). If an actor feels that a procedure has been properly followed, he or she will be much more likely to accept the outcome (Colquitt et al., 2001). In the same manner, fair procedures can mitigate the ill effects of unfavorable outcomes (Cropanzano et al., 2007). To create a fair process, it is necessary to consistently apply three mutually reinforcing principles: engagement, explanation and expectation clarity. "Engagement" refers to involving individuals in decisions that affect them by asking for their input and allowing them to debate the merits of one another's ideas and assumptions. "Explanation" means that everyone involved and affected should understand why a given decision has been made. Finally, "expectation clarity" requires that once a decision is made, the leaders state clearly the new rules of the game (Kim and Mauborgne, 1993, p. 6). To conclude, the organizational justice literature emphasizes that merit is the principle at the core of decisions concerning employees but also argues that this principle alone is not sufficient. Procedural justice mechanisms, in particular, can help in creating the overall feeling of a fair organizational climate.

\section{Justice in the family business domain}

As already mentioned, to apply justice theory within the family business context it is necessary to take into account that the family business is a system consisting of three overlapping subsystems: family, business and ownership (Tagiuri and Davis, 1996). Certain implications of this intertwinement manifest themselves in the decision-making process during succession, as perspectives from the family, business and ownership spheres interact and compete. In family businesses, ownership decisions will be affected by family and business justice perceptions. The decision regarding who will take over the business can be viewed from the family domain (for example, how to choose among children?), the business side (for example, who has the best capabilities and strongest motivations?) and the 
ownership perspective (for example, how to transfer ownership, to whom to transfer it and how to distribute it?). The way in which decisions are made during the succession process is based largely on the guiding rules of conduct applied by the parents and successor(s) as the key decision makers. Moreover, whether the outcome is perceived as fair depends on the individual principles used to evaluate the outcome. The fact that actors may apply different principles of justice makes the evaluation more complex. For instance, when a father chooses a successor from among his children on the basis of who has shown the most effort in the past, this outcome will be difficult for a non-successor to accept if he or she evaluates the decision in relation to the principle of equality, believing that every sibling should receive the same amount regardless of effort shown.

An important contribution to understanding justice in the family business domain is the seminal article by Van der Heyden et al. (2005). They argue that since each family business subsystem has a different main guiding principle defining a fair distribution, the interactions among the different spheres make it highly unlikely that stakeholders will come to similar judgments and therefore "an exclusive focus on distributive justice within family firms may engender more conflict and disagreement than resolution" (Van der Heyden et al., 2005, p. 7). The authors suggest that a way to resolve these issues can be found in the principles of procedural justice: the implementation of a fair process should help to establish trust, commitment and harmony (Carlock and Ward, 2001; Cropanzano et al., 2007; Van der Heyden et al., 2005).

Since the organizational justice literature reveals that distributive justice is more salient than procedural justice, with a greater influence on the more specific, person-referenced outcomes (see Colquitt et al., 2001) that are found in cases of family firm succession, we argue that procedural justice may help only partially in sustaining family harmony during succession. In many cases, the outcome of the succession process is an unequal treatment of siblings in various respects, and therefore procedural justice is probably not sufficient to maintain family harmony. Moreover, to understand sibling relationships and their impact on family harmony, it seems necessary to gain a deeper understanding of the application of distributive justice in the context of family firm succession. The extant literature does not provide insight into how members of a family business, specifically siblings, deal with the combination of the different guiding principles. Therefore, it seems necessary to combine knowledge about family justice and organizational justice theory to understand the complex family business context.

In addition to merit, equality and need as guiding criteria for distributive justice, there are other mechanisms to take into account. In the literature, the potential influence of traditions, such as the principle of primogeniture (i.e. inheritance by the first born) and preferences for a male successor (Byrne et al., 2018) are acknowledged as common rationales behind the choice of a successor. It seems important to consider gender and primogeniture as possible alternative principles of distributional justice (Kissling et al., 2017) and include the impact of such principles on non-succeeding siblings' perceptions of justice.

\section{Family farm succession - a unique context}

We argue that family farm succession offers a unique context in which to investigate how non-succeeding siblings perceive fairness in family firms. Compared to other family businesses, farms engender stronger emotional ties between family members, where gender roles and expectations operate differently, while the farm is a place of residency as well as a place of work and there is often a strong emotional attachment to the farm and the land. Moreover, the transfer to the next generation is financially difficult: the low returns from the farm in combination with a high equity value of the property lead to a lack of free cash flow with which to compensate non-succeeding siblings. 
A farm is a place of family residency and work (Blanc, 1994; Gasson and Errington, 1993) with a strong impact on the socialization of farming children (Dumas et al., 1995; Wiley et al., 2005). Due to mechanization, these days most of the work on farms in Western Europe is handled by members of the nuclear family, with little need for external employees (Calus and van Huylenbroeck, 2010). The work relations in family farms are generally based on ties of love, duty and loyalty rather than on the maximization of economic efficiency. Wallace et al. (1994) refer to this as a "household work strategy," and as a consequence of this strategy children become accustomed to work on the farm in order to help the family. Children from farms describe their family relationships as closer and as more supportive than those from non-farm peers (Quinn and Halfacre, 2014). Moreover, they appreciate the experience of being raised on a farm, and their self-identities accentuate the values of hard work, independence and responsibility (Esterman and Hedlund, 1994). One effect of this particular socialization process is that farm children feel attached to the farm and generally have a strong desire to continue the tradition of farming in the family. This is described by Cassidy and McGrath (2014) as children being "culturally scripted" to retain the farm in the family.

Research suggests that a set of rules governs the choice of successor, although parents are reluctant to acknowledge explicitly that they apply these rules (Keating and Little, 1997): farming families seem to prefer a single-farmer system; moreover, they tend to prefer boys over girls in the succession process (Byrne et al., 2018; Gasson and Errington, 1993). Additionally, capabilities also influence the choice of successor (Keating and Little, 1997). In line with these implicit rules, family farm successors often "exercise little conscious choice in becoming farmers themselves" (Gasson and Errington, 1993, p. 91). As the children in the family grow up, one of them is implicitly selected and knows that he or she has the opportunity to succeed his or her parents when they retire (Keating and Little, 1997). In parallel, the other children realize that they will not take over the farm and that their future lies elsewhere (Keating and Little, 1997). The successor makes the final decision as to whether he or she is really committed to the farm and the lifestyle (Dumas et al., 1995), and sometimes unexpected circumstances or critical events in the family life cycle have an impact on this selection process.

Non-successors seem to accept the selection of the successor as something akin to a "natural order" (Cassidy and McGrath, 2014). For them, the continuation of the farm by their sibling guarantees access to the farm and serves as a source of family pride. The sale of the farm for monetary gain would feel like an act of betrayal, as family members see the farm more as an emotional asset than as a financial one (Glover and Reay, 2015). "While it is the responsibility of the farmer to preserve the legacy, the non-succeeding siblings facilitate and ease this handover of the farm from one generation to the next through not viewing the farm as something they can legitimately take a share of or exhort to be sold" (Cassidy and McGrath, 2014, p. 409). In this way, the "cultural script" leads the non-successors to accept the situation and the unequal wealth outcome that is its consequence. The parents may aim to compensate the non-succeeding children with other assets or opportunities (Keating and Little, 1997); however; the financial situation of the farm may make this difficult to achieve. The farm cannot be split in order to give children an equal share because this will jeopardize continuity, and so the farm must be transferred to the successor at a value below the market price of the land and the estate (Van der Meulen et al., 2015).

Although non-succeeding children generally seem to value the continuation of the family farm and, in most cases, show little resistance to transferring the business to one of their siblings (Sues-Reyes and Fuetsch, 2016), they do not necessarily evaluate the succession process and its outcome as fair. Anecdotal evidence reveals many disputes within families about the unequal distribution. So far, little research has explored this theme. One exception is a study by Taylor and Norris (2000), who demonstrate that disagreements between 
succeeding and non-succeeding siblings about rules of fairness are related to conflicts over family farm transfers.

It seems important to gain a deeper understanding of how non-successors judge the outcome of the succession process in family firms because feelings of unequal treatment can harm family relationships and have a negative impact on the perpetuation of the firm in the long run. The family farm offers a unique context for this exploration. Therefore, we formulate the following central research question: How do non-succeeding siblings perceive justice with regard to family firm succession?

\section{Method}

In this section, we describe the research context and the methods used, including data collection and data analysis.

\section{Research context}

Our research context is the Dutch agricultural sector. The majority of agricultural businesses in the Netherlands are family farms. Moreover, the majority of the labor on $87 \%$ of these farms is performed by family members (Backus et al., 2009). The Dutch agricultural sector has changed dramatically in recent years. Through mechanization and expansion of scale, farms have become larger and more capital intensive, while the number of farms has steadily declined (Calus, 2009; Eurostat, 2013). At the same time, the contribution of Dutch farms to the global food supply has increased (FAO, 2014). Nearly a quarter of farmers in the Netherlands are 65 or older, making agriculture one of the most aging sectors in the country (CBS, 2015). Moreover, succession within the family is no longer taken for granted (Van der Meulen et al., 2014). The higher level of education of most successors makes alternative career paths attractive, especially given the low return on investment in family farms (an average of 1\%) (Braaksma et al., 2012).

In the Netherlands, the designated successor typically works with his parents on the family farm and becomes, at a young age, part of the so called maatschap, a legal structure that organizes ownership (Matser and Slager, 2017). This structure allows the successor to gradually increase his or her share in the farm's ownership while the parents are still too young to retire. The Dutch government facilitates the transfer of ownership through reduced inheritance and gift taxes when the beneficiary has been involved in the business for at least one year prior to the transfer and he or she continues to work in the business for at least another five years (KPMG, 2018; Matser and Slager, 2017). The Dutch government has additional tax arrangements to facilitate succession in the agricultural sector. The goal of these arrangements is to support farm continuity by further reducing the gift tax that must be paid.

The "legitimate portion" is another relevant factor in relation to the transfer of farms in the Dutch context. This term refers to the minimal part of the inheritance to which a child of the deceased is entitled, despite wills and donations made by the deceased. The value of the legitimate portion is half of what the child would receive given an equal distribution among the children and spouse of the deceased. Therefore, the fact that the tax system reduces the gift taxes that are applicable when one child takes over the farm may conflict with the other siblings' legitimate portions. In the Dutch courts, a claim from siblings in such situations is seldom honored (Matser and Slager, 2017). The main argument for not complaining is that doing so could harm the continuity of the business. If it is plausible that the value of the business that has been paid is the maximum in light of the farm's continuity, then the tax exemption does not lead to a civil donation, and therefore it does not affect the legitimate portion. Anecdotal evidence from the Netherlands reveals many examples of cases in which the transfer of a farm to one of the children leads to conflicts over the inheritance. 
Despite the vast literature on family firm succession and organizational justice, relatively little is known about the application of principles of justice by family members during the succession process. To investigate how families sustain harmony during succession and why non-succeeding siblings grant the farm to successors and accept negative wealth consequences for themselves, we used a case-study methodology. Case studies have the potential to generate in-depth insights into empirical phenomena and their contexts, and these insights can be used to refine theory (Dubois and Gadde, 2002). Furthermore, the casestudy approach allows for adaptability, and it is suitable for studies involving "how" and "why" questions (De Massis and Kotlar, 2014). To understand the role and justice-perceptions of non-successors, we used the family as the unit of analysis and interviewed multiple family members. Based on interviews with family members with different roles as well as secondary data, we built case descriptions, which evolved during the project as we analyzed and reanalyzed them, compared them and tested them against the literature.

Our research started with an empirical phenomenon (the granting factor in the context of succession in family farms) that was difficult to explain using extant theory. Given the complexity of the phenomenon of interest, the limited existing knowledge and the nature of the study, which is geared toward discovery, we used an abductive research approach (Dubois and Gadde, 2002, 2014; Van Maanen et al., 2007). During the study, we learned that non-successors play an important role in the succession process. We discovered that fairness and the "granting factor" are important for succession in family farms. Therefore, we returned to the fairness and organizational justice literature and used the frameworks of distributive and procedural justice. By systematically combining and simultaneously conducting empirical fieldwork and case analyses and by developing a theoretical framework (Dubois and Gadde, 2002), we refine the extant theory of justice.

\section{Data collection}

Data were collected through a large qualitative research project in the Netherlands called "Family farm succession: From kitchen table to family constitution." Between 2015 and 2017, data were collected from 14 family farms. A purposeful sampling technique was used to select cases that exhibited the characteristics of the phenomenon of interest (Emmel, 2013). The selected cases are information-rich, unique and revelatory research sites (Langley and Abdallah, 2011) for studying the role of non-succeeding siblings in the context of succession in family farms. The farming families who participated in our project were found in two ways: (1) the project was announced in an agricultural newspaper and (2) we directly contacted families who had indicated in an earlier mail survey their willingness to participate in future research on succession. For most farming families, the motivation to participate was related to their desire to include all family members in the succession process. In many families, this desire was stimulated by negative experiences in previous succession processes - they hoped that they could prevent similar issues from arising in the future by participating in the project. Thus, the families already had awareness that succession is a process that involves not only the incumbent leader and successor but also the other siblings.

The interviews were conducted by teams of two researchers who visited each of the family farms. For each family, we explicitly requested an interview with each family member or, when this was not possible, with at least one person in each role- successors or potential successors, incumbent leaders, spouses and non-succeeding siblings. For practical reasons it was sometimes not possible to interview all family members. In such cases, we let the families decide who would be interviewed, as long as each role was represented. In total, more than 60 semi-structured interviews were held with successors or potential successors, incumbent leaders, spouses and non-succeeding siblings. The interviews were designed to allow family members to provide details about their experiences and their perceptions of their businesses, 
families and the succession process. All interviews were recorded, transcribed and summarized prior to analysis. In addition to gathering data from the interviews, we collected background information on farm characteristics with a short questionnaire administered prior to the interviews with incumbent leaders. We included questions about such matters as main activities, sideline activities, size of the farm (hectares and production volume), type of land and possibilities for extension of the farm. This information helped us better understand the business context of each farm, which was helpful in interpreting the findings from the interviews.

As the focus of our research was on non-succeeding siblings' perceptions of justice with regard to family farm succession, the interviews with those siblings served as our primary data source. We collected data from 12 non-succeeding siblings from 8 different families in different stages of the succession process. At least one non-successor was interviewed in each family, and in two families (cases 3 and 4) we interviewed two non-succeeding daughters at the same time. In addition, we used the interviews with the incumbents and successors in these families to gain a better understanding of how the decisions relating to the succession had been made and how the succession process had been organized. Additional secondary data were used to improve our understanding of the context and complement the findings. As part of the larger research project, we also organized workshops and "kitchen table conversations" in which all family members participated.

We used a topic list to guide the interviews (see the Appendix). In addition to general topics related to family farm succession, we included topics centered on how family members perceived justice. More specifically, the interviews covered the following areas: family context, the history of the farm as a family business, the business situation, the succession process, communication between family members and fairness. During the interviews, one of the researchers asked open-ended questions, while the second made notes and asked followup questions when necessary. This system was used throughout the project in order to build trust with the families and to enable the families to become familiar with the researchers. Most of the interviews were held at the family farms in a private setting, often at a kitchen table. However, in some cases the non-succeeding siblings came to our university or we interviewed them in their own homes. The interviews lasted an average of $70 \mathrm{~min}$ and ranged from $55 \mathrm{~min}$ to $120 \mathrm{~min}$ in length.

Table 1 provides an overview of the types of family farms, the composition of the families, the generation that was running each farm, the stage in the succession process and the characteristics of the non-succeeding interviewees.

Five of the family farms in our sample were dairy farms. The other farms included a veal business; a diversified farm with young cattle, a bed and breakfast and an art gallery and a mixed farm with dairy and pork. The farms were all situated in the northeastern part of the Netherlands. Dairy farms are overrepresented in this region compared to other parts of the Netherlands (CBS, 2016). Most of the farms were third- or fourth-generation family businesses, which is common in agriculture (Gasson and Errington, 1993). In all cases, the successor or potential successor was a son, but he was not always the eldest child. In cases 3 and 4 , the male successor was the youngest child in a family with older daughters. In nearly all cases, there was room for only one or two successors. However, in case 5, the parents were trying to find suitable roles for all of their sons. As the mother stated, "We feel it is important that our sons stay connected to farming." As veal farms are less dependent on land than dairy farms, it is easier to enter or exit this type of business. Most of the cases were still in the pre-succession stage: although the successors had been chosen, the parents were still working on the farm because they were too young to retire. However, in case 2 , the farm had already been transferred and the parents were retired. Although the parents in case 4 had nearly reached retirement age, they were still working on the farm together with their youngest son. 
JFBM

\begin{tabular}{|c|c|c|c|c|c|c|}
\hline & Farm type & $\begin{array}{l}\text { Family } \\
\text { composition }\end{array}$ & $\begin{array}{l}\text { Current } \\
\text { generation }\end{array}$ & $\begin{array}{l}\text { Stage in succession } \\
\text { process and } \\
\text { ownership }\end{array}$ & Interviewees & Work experiences \\
\hline 1 & Dairy farm & $\begin{array}{l}\text { Parents (<65 years } \\
\text { old, still working), } \\
\text { one daughter ( } 28) \\
\text { and two sons ( } 26 \\
\text { and } 25) \text {. Youngest } \\
\text { son with girlfriend }\end{array}$ & 4 th & $\begin{array}{l}\text { Parents are owners } \\
\text { and want to hand } \\
\text { over in the next } \\
\text { five years. } \\
\text { Youngest son is the } \\
\text { only potential } \\
\text { successor but still } \\
\text { not a member in the }\end{array}$ & $\begin{array}{l}\text { Incumbents: } \\
\text { father, mother } \\
\text { Potential } \\
\text { successor: } \\
\text { youngest son } \\
\text { Non-successor: } \\
\text { daughter }\end{array}$ & $\begin{array}{l}\text { Mother is not working } \\
\text { on the farm anymore } \\
\text { Youngest son works for } \\
\text { a salary on the farm } \\
\text { Daughter works } \\
\text { part-time outside the } \\
\text { farm }\end{array}$ \\
\hline
\end{tabular}
2 Dairy farm $\quad \begin{aligned} & \text { Parents }(>65), \\ & \text { eldest daughter }\end{aligned}$ (38, married with children) and three sons. The two youngest sons are married with children

3 Dairy farm Parents $(<65)$. Three daughters, (21, 23 and 26); two are married with children.

Youngest son (19) is single and still living at home with parents

4 Dairy and crop farm

5 Veal farm

Parents $(<65)$, three daughters and three sons. Daughters are married with children. One son (29) married with child. Other sons (21 and 19) are single

Parents (>65), three daughters (33, 35 and 36 ), married with son (28) with girlfriend 4th$$
\text { Farm was }
$$

transferred seven

years ago to the two youngest sons

Parents are working partners and owners Youngest son (19) will succeed parents in 10 years

Partnership agreement between parents and youngest son in place for past eight years. Parents want to retire very soon. Youngest son and partner will succeed

Parents have their own veal farm and work together in a special business structure with eldest son (24) who also has a veal farm. Parents want to retire over 10 years Two other brothers can succeed the parents in businesses at different locations
Incumbents: Parents are retired

parents

Successors: son One successor is also 1 and son 2 working outside the farm

Non-successor: Daughter does not eldest daughter work Non-succeeding son has own career

Incumbents: father, mother Potential successor: youngest son Non-successors: two daughters together and one daughter separately

Incumbents: father, mother Potential successor: youngest son Non-successors: two daughters together

Incumbents: father, mother Successor: oldest son Non-successors: son 2 and son 3 Parents working on the farm

Son still going to school and working part-time outside the farm. Daughters with own careers elsewhere

Father is still working Girlfriend working unpaid Daughters having their own careers elsewhere

Parents work on the veal farm Oldest son working on his veal farm Other sons working elsewhere or still going to school
Table 1.

Overview of farm types and interviewees 


\begin{tabular}{|c|c|c|c|c|c|c|c|}
\hline & Farm type & $\begin{array}{l}\text { Family } \\
\text { composition }\end{array}$ & $\begin{array}{l}\text { Current } \\
\text { generation }\end{array}$ & $\begin{array}{l}\text { Stage in succession } \\
\text { process and } \\
\text { ownership }\end{array}$ & Interviewees & Work experiences & $\begin{array}{l}\text { Faurness } \\
\text { perceived by } \\
\text { non-successors }\end{array}$ \\
\hline \multirow[t]{2}{*}{6} & \multirow[t]{2}{*}{$\begin{array}{l}\text { Diversified } \\
\text { (young cattle, } \\
\text { B\&B, art } \\
\text { gallery; } \\
\text { previously } \\
\text { dairy) }\end{array}$} & \multirow{2}{*}{$\begin{array}{l}\text { Parents }(<65) \text {, } \\
\text { three daughters } \\
\text { and one son. } \\
\text { Daughters are } \\
\text { married with } \\
\text { children. Son with } \\
\text { girlfriend }\end{array}$} & \multirow[t]{2}{*}{4 th } & \multirow{2}{*}{$\begin{array}{l}\text { Father and mother } \\
\text { want to retire over } \\
\text { four years. } \\
\text { Different } \\
\text { partnership } \\
\text { agreements in } \\
\text { place: parents with } \\
\text { son and one } \\
\text { daughter for the } \\
\text { bed and breakfast, } \\
\text { father with his } \\
\text { uncle for the young } \\
\text { cattle farm. Son } \\
\text { runs the bed and } \\
\text { breakfast. Mother } \\
\text { and daughter run } \\
\text { the art gallery }\end{array}$} & $\begin{array}{l}\text { Incumbents: } \\
\text { father, mother } \\
\text { Successor: son }\end{array}$ & $\begin{array}{l}\text { Father doing } \\
\text { different farm-related } \\
\text { activities } \\
\text { Mother works in her } \\
\text { art gallery }\end{array}$ & \\
\hline & & & & & $\begin{array}{l}\text { Non-successor: } \\
\text { daughter }\end{array}$ & Son manages B\&B & \\
\hline 7 & $\begin{array}{l}\text { Dairy and } \\
\text { pork farm }\end{array}$ & $\begin{array}{l}\text { Parents }(<65) \text {, one } \\
\text { son }(21) \text { and one } \\
\text { daughter }(20) \text { still } \\
\text { living at home } \\
\text { with parents }\end{array}$ & 3rd & $\begin{array}{l}\text { Parents are owners } \\
\text { and business } \\
\text { partners and want } \\
\text { to retire more than } \\
\text { ten years from } \\
\text { now. Son will } \\
\text { succeed parents }\end{array}$ & $\begin{array}{l}\text { Incumbents: } \\
\text { parents } \\
\text { Successor: son } \\
\text { Non-successor: } \\
\text { daughter }\end{array}$ & $\begin{array}{l}\text { Parents work on the } \\
\text { farm } \\
\text { Son and daughter } \\
\text { still going to school } \\
\text { and working on the } \\
\text { farm in their free time }\end{array}$ & \\
\hline 8 & Dairy farm & $\begin{array}{l}\text { Parents }(<65) \text {, four } \\
\text { sons, one youngest } \\
\text { daughter (all } \\
\text { between } 16 \text { and } 25 \\
\text { years old). All } \\
\text { children still living } \\
\text { at home except for } \\
\text { one son }\end{array}$ & 3rd & $\begin{array}{l}\text { Parental business } \\
\text { partnership. Two } \\
\text { potential } \\
\text { successors }\end{array}$ & $\begin{array}{l}\text { Incumbents: } \\
\text { father, mother } \\
\text { Potential } \\
\text { successors: son } \\
1 \text { and son } 2 \\
\text { Non-successor: } \\
\text { one son }\end{array}$ & $\begin{array}{l}\text { Father works only on } \\
\text { the farm } \\
\text { Three sons work on } \\
\text { the farm in free time } \\
\text { One potential } \\
\text { successor still going } \\
\text { to school. Other } \\
\text { potential successor } \\
\text { son working } \\
\text { elsewhere }\end{array}$ & Table 1. \\
\hline
\end{tabular}

Most of the non-succeeding siblings were relatively young (mean age: 19.7 years), still living with their parents and in education. In cases 2, 3, 4 and 7, some of the non-succeeding siblings had already left the farm, launched their own careers and married and/or had children of their own. The mean age of the siblings who had already left the farm was 31.8 years.

\section{Data analysis}

As the first step in the data analysis, we read transcripts of the interviews with all different stakeholders. We took notes, discussed key issues and identified recurring themes in the data. We also noted commonalities and differences among family members and discovered several topics that were specific to the roles played by those family members in the succession process. In particular, we found that non-succeeding siblings play an important role in facilitating the succession process. Therefore, in the second step of data analysis, we focused on the interviews with non-succeeding siblings. We used the theory of organizational justice as a conceptual lens through which to analyze the data and to understand how nonsucceeding siblings perceive justice. We adopted Colquitt et al.'s (2001, p. 425) definition of distributive justice as "fairness of the outcome distributions or allocations" and of procedural justice as "fairness of the procedures used to determine the outcome distributions and allocations.” 
Interview transcripts were coded by identifying quotes related to the different components of procedural and distributive justice. We then grouped the interview quotes into themes related to the principles of justice applied by parents and prospective successors, the perceptions of justice held by non-succeeding siblings and the acceptance of the outcomes of the succession process. This grouping process allowed for a purposeful examination of the data and helped us uncover content-based data related to our research question (MacQueen et al., 2008).

\section{Findings}

To explore how non-succeeding siblings reflected on the process of decision-making regarding surrounding family farm succession and its outcomes, we categorized the findings on the basis of indications of distributive and procedural justice using the justice framework. To achieve an overall understanding, it was also necessary to explore perceptions of fairness and outcomes of the parents and the successors and to test for variance between these groups and the non-successors. Therefore, the starting point for our analysis was the findings from the interviews with parents and successors. Next, we analyzed the interview data gathered from non-succeeding siblings. We discussed their perceptions about fairness with regard to the choice of a successor, needs in the family sphere and the resulting distribution of property. Based on these findings, we derived a model of how non-successors evaluate the fairness of family firm succession, shown in Figure 1.

The model shows the relationships between the justice principles applied by incumbents and successors and the acceptance of the outcome by non-succeeding siblings. The applied combination of principles of distributive justice (merit, needs, equality, primogeniture and gender) with those of procedural justice by parents and prospective successors has a direct impact on the acceptance of the outcome of the succession process by non-successors. We propose that this relationship is moderated by how non-succeeding siblings evaluate the justice of the process and the outcome. Therefore, the middle part of the model distinguishes between the evaluation of the procedural justice (fair process) of the succession process by non-succeeding siblings and the evaluation of the fairness of the outcome, which depends on how non-succeeding siblings combine and weigh the various perspectives of distributive justice. We group the findings of our study in this section accordingly. We begin by discussing the themes mentioned by parents and successors that are related to the justice principles they applied in their decision-making during the succession process.

Figure 1.

Model of fairness perceived by non-successors
Applied justice principles The applied combination of distributive justice principles (merit, needs, equality, primogeniture $\&$ gender) and procedural justice principles by parents and candidate successors

\section{Fair process}

Non-succeeding siblings

evaluate the procedural

justice of the succession

process

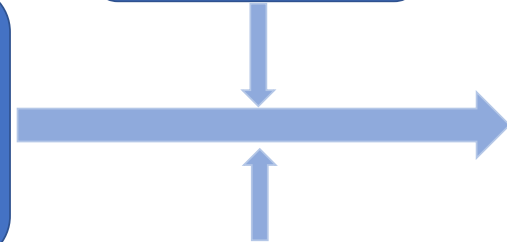

Fairness of the outcomes Non-succeeding siblings combine and weigh the various perspectives of distributive justice and evaluate the outcome
Acceptance of the outcomes Acceptance by the nonsucceeding siblings of the outcomes of the succession process 
Justice principles applied by parents and successors in decision-making during the succession process

\section{Past experiences of incumbents}

Most parents were once successors themselves. They reflect on their own succession experiences as they prepare for the present succession. The interview data show that in the past it was quite normal that a motivated son should take over the farm. Some male parents did not remember exactly how they had become farmers, "as if I was automatically driven into that position" (case 1). According to the father in case 8, it had been taken for granted that he would be the next successor, "since it was out of the question that one of my sisters would become a farmer." In case 3, there was a sister who had had ambitions to farm, but she had been neglected by her parents. "For her it was very painful, mostly because it was never openly discussed" (case 3). In some cases, the transfer of the farm had led to painful disputes. "Pushed by her husband, my sister fought for her share of the farm. Only after many painful negotiations, she finally agreed with a lower sum of money" (case 1). In case 4 , an accountant had played an important role in convincing the sister, whose own business at that time had gone bankrupt, that claiming her share would destroy her brother's farm business. The wife and co-owner in case 3 remembered that she had had to deal on a daily basis with her sister-inlaw who did not accept the outcome. "In the past, my husband, me, and my parents-in-law went to the notary for the formal partnership agreement. We never informed the other siblings about it, which I nowadays regret and acts as a learning moment how to deal with our succession in the future" (case 3).

From these findings it seems that incumbents' perceptions about succession and the fairness of its process are influenced by personal experiences in the past, especially where incumbents themselves were successors. On the one hand, they can take traditional views about gender issues in the process of succession for granted. On the other hand, however, looking to the future, they can be motivated to avoid the sorts of conflicts that have arisen in the past. Reflecting on the past, the actors involved acknowledged that there should have been more attention given to procedural justice. Based on their past experiences, farmers formed ideas about the succession process in the future and about what should be prevented or stimulated in that process.

\section{Traditional views about farming}

Traditional views about farming, such as those relating to gender, still serve as a justification for the choice of successor. Without exception, all prospective successors in our cases are men. The father from case 5 explicitly said that "farming is no business for women, because it is too heavy." His wife agrees: "I must confess that we are still very old-fashioned. We think more about the boys than about the girls." In case 4, only the youngest child is a male. "Although we have one daughter who was interested in farming, we asked our son to become the next farmer." The father in case 3 doesn't worry that his only son is more interested in machines than in cows, "because I had the same attitude at his age" (case 3). At the same time, he criticizes the work ethic of his daughters, who "never worked full-time on the farm during summer holidays and never milked cows or told me that they wanted to learn this" (case 3). Some parents question the motivation of their sons to become farmers. "Right at the moment, I cannot take a step back," the father from case 1 said, "because I still have too much doubt about my son as a potential successor." However, the parents nevertheless see him as the only suitable candidate in the family to take over the farm, and so they stimulate him to gain more knowledge and experience. "My parents pushed me to do an agricultural degree, but this turned out to be too much for me. Still, I feel the urge to preserve the continuity of our fourth-generation family farm. I would never accept it being sold" (son, case 1).

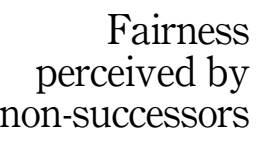


In the eyes of many parents, farming is still a business for men. As a result, they do not consider their daughters as prospective successors. Even when there are doubts about the willingness and capabilities of their sons, parents still keep alive the hope that eventually their sons will be good farmers and that the farm will continue into the next generation. It seems that most parents still hold the traditional view that succession of a son to a farm is the only option.

\section{Unequal division of the family equity}

In general, it can be said that both parents and successors are reluctant to share the business with the other siblings. "My opinion toward my own children is that those who didn't work on the farm don't deserve a share in the farm transfer" (father, case 1). However, this attitude does not mean that parents are not troubled by the unequal situation that is created. The parents in case 2 feel ashamed that the capital cannot be equally distributed between the children. "We were advised by our accountant to withhold financial information about the business value. We were scared that it would be a source of conflict between our children. With money from a subordinated loan, we try to help the other two children" (Parents, case 2). Parents realize that there are alternatives that would lead to a more equal distribution of the equity. These options are dismissed, however, because parents are afraid that they will make it difficult to run the farm. The father in case 4 said it might be fair that "my daughters would own a total of 33 or even 50 percent of the land and earn an income from renting it. But this would also create the possibility they interfere with the business and harm the continuity of it."

Overall parents are reluctant to share the family equity with all children equally although they sometimes feel ashamed that they are not able to do this. They prioritize the continuity of the farm and want to create, based on their knowledge and experiences, the most optimal situation for the successor.

\section{Family and business factors sometimes create room to maneuver}

In some situations, the transfer of the farm and distribution of the family property is less complex. The parents from case 7 think that their daughter will accept the farm transfer because "we can help her financially by giving her the house with some piece of land" (parents, case 7). Whereas in case 7 it is helpful that there are only two children, in cases 5 and 6 the situation is made easier because of the nature of the business. Case 5 is a veal business, which entails that the farm is less dependent on land and therefore not tied to a specific location. "I think it is possible in the future that at least two brothers could have their own branches at different locations and that we would still cooperate with each other in a business structure" (son, case 5). In case 6, the father stopped producing dairy and sold much of his land. In addition to raising young cattle, the parents run a bed and breakfast (B\&B) and an art gallery. This diversification has created different succession alternatives. At the moment, one son is managing the $\mathrm{B} \& \mathrm{~B}$ and a daughter is helping with the gallery. However, if the children's plans change, the parents state that they would consider stopping the business or selling it outside the family. Another aspect that may create room to maneuver is the family life cycle. In at least four cases $(3,5,7$ and 8$)$ the parents are far from the age of retirement. "I am still too young to stop, while the farm is for me and my son too small for a full-time job. Therefore, it is wise that he works for a while somewhere else. He will gradually become my business partner, while my wife will gradually pull back from the partnership" (father, case 3). For the only son and potential successor in case 7, "the young age of my parents creates the possibility of a long period of partnership and working in parallel; it allows me to do something else or even go abroad to work elsewhere" (son, case 7).

To summarize, parents sometimes find ways to maneuver and treat their children more equally. For small families, it can be easier to divide wealth on a more equal basis than it is in 
larger families. Farm types that are less dependent on land can more easily be transferred to more than one child, and, depending on the age-gap between parents and successors, alternative ways can be found to make a living.

\section{Mixed feelings about communication}

Twice a month, the two brothers in case 2 and their wives come together to talk about workrelated issues. In other families as well, there is an understanding of the need to communicate. "New Year's Day is a special moment for us when we as a family openly discuss our feelings and handle emotions" (mother, case 1 ). Another example is the father in case 3 , who expresses the need to talk with all his children: "For keeping the peace, it would be nice that we have a family plan. Succession shouldn't be a discussion about money. Knowing each other's wishes and values is important. For instance, I want to know if there is still a place for me on the farm after my retirement" (father, case 3). However, there are sometimes differences between family members. For example, the mother in case 8 criticizes her husband for rarely discussing matters with his sons, let alone with his daughter. Furthermore, there is the distinction between the decision-making process itself and informing and explaining that decision. As the successor in case 4 explained, "My opinion is that basically all decisions about succession are made only by me and my parents, without any involvement of my sisters. They should accept the outcomes of it, and therefore a written business plan is needed." He is scared about "the possibility that my sisters will complain about the succession process. They could say something like, "He will inherit everything against a low price, while we as daughters receive nothing." For this reason, I want to write a business plan. With this plan I hope they will understand that the low transfer price I pay for the farm is needed to continue the business."

While farm families realize that communication is important, it is not organized structurally and formally. Matters of succession are not discussed frequently or systematically with all family members. A written business plan may be used to create a better understanding of the farm transfer for the non-successors.

\section{Perceptions of non-succeeding siblings about the justice of the succession process and the decision-making surrounding it \\ Merit as a basis for choice of successor}

The main decision during the succession process is the choice of a successor, which is primarily made by the parents. Whereas parents acknowledge the preference for a male successor, non-succeeding siblings seem to focus on the capabilities and motivation of the successor and compare this with their own. The 18-year-old son in case 8 who liked to work on the farm after school perceived his parents' choice as fair: "My two older brothers [who will take over the farm] work harder than me and are more motivated to become farmers." He also understood that asking for an equal share would harm the transfer of the farm to the succeeding brothers: "What would there be left for my brothers if all of the property was equally divided among the siblings?" His ambition after finishing high school was to study at the university: "In the future, I want to become a veterinarian. In that case, I can take care of myself." Non-succeeding siblings without experience working on the farm, like the sisters in cases 1 and 6, were convinced that succession rights should be earned: "I never worked on the farm, and I do not know what is going on. Therefore, I have to ask myself whether I have a right to get involved" (case 6). Non-successors felt it was important that the succeeding siblings were motivated to work hard. The sister in case 1 expected full commitment and responsibility from her brother: "He should go for it for the full $100 \%$, not for $99 \%$. He should be motivated $200 \%$." The sisters in cases 3 and 4 did not envy the succeeding brother's wealth but indicated that they would blame him if he were to sell the farm: "Let's give him his share, 
but it should be precisely documented, so that he will not sell the business in five years and become rich" (case 3).

The preference for a male successor is sometimes questioned. The sisters in case 3 were critical and asked why their brother had been automatically chosen: "Does he have the skills? Is he motivated enough?" This query relates to the fact that most of the women had working experiences on the farm but these were "women-related": activities in the kitchen or cleaning activities on the farm. "If something important had to be done, our father always asked our younger brother. We were never asked to drive the tractor or milk the cows. Our place was in the kitchen. We were needed only for harvest activities during the summer" (daughters, case 3 ). Still, the cultural script, which is focused on a strong and hardworking male family member as the future farmer, seems to hold. For instance, one of the sisters in case 3, instead of mentioning herself or her sister, said that her husband was motivated to take over the farm if her younger brother did not become the successor.

To summarize, non-succeeding siblings seem to use merit as a basis for evaluating the outcome of the succession process. They compare their own motivation, capabilities and work on the farm with those of the successor. However, they also take the needs of their sibling into account; they realize that if they were to claim an equal part of the property, this would ruin the future for their brother. For them, it is important that the successor is motivated to run the business and accepts his responsibility to keep the business in the family.

\section{Needs as a basis for decisions in the family sphere}

The choice of a successor is accompanied by related decisions in the family sphere, such as the question of where the parents will live after the successor takes over the farm. We analyzed the interviews to understand how siblings evaluated decisions in the family sphere and how they took their own needs into account. Young non-succeeding siblings who still lived with their parents did not have well-described personal needs, but they recognized that claiming their share would harm the successor's need for success as a farmer. In general, these siblings were oriented toward their own future careers as a way to achieve financial independence. Non-successors revealed non-financial reasons for keeping the farm in the family. The sisters in case 4 were proud that their brother wanted to uphold the family tradition of farming, which they viewed as "hard, poor, and risky." The farm symbolized the family's identity, as it was a place where many generations had already resided. For the sisters in case 3, who lived elsewhere, the farm and the surrounding area represented "the most beautiful place on Earth" - a place where they could spend time with their parents and siblings. They realized that their need for such a place could only be fulfilled if the farm was transferred to their brother. The daughter in case 7 had an explicit reason for keeping the farm in the family - she needed it as a place to train her horses, as she is a semi-professional horse rider in her free time. The non-succeeding children we interviewed expressed concerns about their parents denying their own financial needs to guarantee a successful succession. They seemed to take this into account when evaluating their rights: "It feels arrogant to ask our parents for our share because they never kept anything for themselves and preserved everything for the business" (case 4).

Siblings with children of their own seemed to take their children's needs into account when evaluating decisions made during the succession process. In case 4, the older non-succeeding siblings said that they might need a larger share of the property because they had to consider the need to finance their children's education. The fact that needs can change over time is clearly reflected in the situation of the sister in case 2, who felt a sense of frustration over the succession process. One important source of this frustration was the fact that her brothers had not granted her husband, who owns a construction business, the contract for remodeling the farmhouse. In this regard, she stated: "I gave you [her brothers] my share of the farm. Why 
didn't you help my husband's business by letting him rebuild the farmhouse?" Moreover, reflecting on her role in the succession process, which had taken place seven years before our study began, she indicated that she had been too naïve. When the final decision was made, she had agreed to renounce any rights to a future share in the family farm, as she trusted that her succeeding brothers would in turn help her if she was in need.

In general, the interviews reveal that non-successors take their own needs (financial and non-financial) into account. However, they also take the needs of other family members, especially their parents, into account. A common, important non-financial need is keeping the farm in the family. Non-succeeding siblings value the farm as a place to spend time with the family, but, even more, they realize how important the continuity of the farm is for their parents. Equality plays a role, with non-successors comparing their own needs with those of their parents and acknowledging the (low) income of the successor. Furthermore, the needs of non-successors can change during the family life cycle, affecting their perception of justice.

\section{Equality in relation to the distribution of property}

The choice of a successor eventually leads to decisions in the ownership sphere. In farming families with many children, the number of non-successors is normally higher than in small families. Siblings who grow up in large families seem to take this into account when evaluating the decision-making. As one non-succeeding sibling in case 8 stated, "The situation would have been different, of course, if I was an only child, but that is not the case." He understood that it was impossible to divide the farm among all five siblings, and he perceived no signs of injustice. A different view was evident in case 7 , a family with two children, a succeeding brother and a non-succeeding sister. The sister expect from her parents a part of the property: "My parents will give me an equal share of the farm. The house will be mine in the future." While non-succeeding siblings seemed to accept that their brother would be the future owner of the farm, they had reservations regarding the dilution of ownership to in-laws. As one sibling in case 4 suggested, "It is hard to see our sister-in-law spending money, as we grew up on the farm and we know what it took to get it this far" (case 4). The sisters in case 3 also had reservations when they thought about the possibility of a future sister-in-law living on the farm, wondering, "Will we be still welcome there?" Next to family factors, the distribution of property among the children also depends on the type of farm. In multifunctional farms, the business is diversified to include different activities. For example, in case 6, the farm encompasses a bed and breakfast, an art gallery and the raising of young cattle. In such a case, there seem to be more possibilities for equal distribution, as the different business activities could be owned and managed by different family members. The daughter in case 6, who worked elsewhere at the time of the interviews, could decide to cooperate with her brother if she so desired: "In the future, if I no longer want to work in the health-care sector, I may help [my brother] with the bed and breakfast."

Farms can be characterized as businesses with low returns on investment and in which all of the capital needs to be reinvested in the business. Therefore, the daily life of farmers is not easy: "My brother's life is hard, poor, and risky" (case 4). The sister in case 1 felt that her poor standard of living was equivalent to her brother's life as a farmer. The sisters in cases 3 and 4 also made it clear that they took the low returns into account. However, in evaluating the ownership position of their brothers, they said that they could never accept their succeeding brothers becoming wealthy by selling the farm.

Non-successors seem to accept an unequal distribution more easily in larger families in which more siblings are involved. In smaller families it is easier to achieve a more equal distribution and to give non-successors part of the property, and this possibility is reflected in the expectations of the non-succeeding siblings. Although non-successors accept the unequal distribution of wealth in favor of their succeeding sibling, they have more reservations about 
the partner-in-law who marries the successor. If the farm is of a type that is less dependent on land ownership, it may be easier to divide ownership between all siblings equally. Finally, non-successors seem to accept an unequal distribution more easily when the income of the successor is relatively low.

\section{Procedural justice}

While distributed justice refers to the fairness of the outcome of the succession process, procedural justice relates to the fairness of the allocation process itself. A fair process respects three mutually reinforcing principles: engagement, explanation and expectation clarity (Kim and Mauborgne, 1993). Communication is a central element in establishing a fair process. Previous research leads us to expect that when non-succeeding siblings perceive the succession process as fair, they find it easier to accept the outcome (Cropanzano et al., 2007; Van der Heyden et al., 2005). Therefore, non-successors were asked how they perceived procedural justice during the succession process. Reflecting on the succession process, the sister in case 2 regretted the absence of family discussions; "I would have felt more comfortable during the succession if all relevant information had been openly discussed and explained with some professional guidance." Some aspects of succession were also difficult for her to understand: "We were still very young when my brothers took over the business. We agreed on matters I did not fully understand." The sisters in case 4 expressed a desire to be kept informed about the succession: "We would like our brother to give us clear information about what he wants. Moreover, we would like to have everything explained in normal written terms." A need for clear, documented agreements with the succeeding brother was also felt in case 3 .

Surprisingly, some non-successors raised questions about the value of procedural justice. The non-succeeding sister from the multifunctional farm in case 6 raised questions about the need for discussions: "Mom and dad want to involve me in the succession process, but dad makes the ultimate decisions, so does it have some meaning or is it just symbolic? I do not see the need for all these talks about succession." The youngest brother in case 8 openly doubted the value of family discussions related to succession: "Why should we discuss it again and again? My brothers will take over the farm and I will become a veterinarian.”

Looking back at the succession process, it becomes easier for non-successors to understand what was missing with respect to procedural justice. However, when the succession process is still ongoing, non-successors seem to have diverse thoughts about the value and necessity of procedural justice. There seems to be a clear need for good communication, but when non-successors feel they have no influence on the process and their voices are not heard, they may become skeptical about being involved.

\section{Acceptance of the outcome of the succession process by non-succeeding siblings}

In all of the cases except case 2, the non-succeeding siblings did not express strong feelings of injustice about the succession process or its outcomes or anticipated outcomes. None of the non-succeeding siblings spoke explicitly about their right to an equal share in the property. In their overall judgments of the perceived fairness of the outcomes, the siblings seemed to combine various aspects of distributive justice. Non-successors realized that they would jeopardize their brothers' occupations if they demanded their share of the property. In return for their support, however, they had high expectations regarding their brothers' motivation, and they only granted them full ownership under the condition of not selling the farm. In addition, the continuity of the farm was seen as a non-financial goal that could be fulfilled by their brother becoming the successor. More generally, the negotiation of multiple family needs makes insistence upon the fulfillment of one's own financial needs difficult. For example, how can a sibling justify asking for a share of the farm when his or her parents have denied themselves almost everything to ensure the farm's continuity? In some cases, 
procedural justice was acknowledged as an important resource in promoting acceptance of the outcome. In other cases, non-succeeding siblings did not seem to see the value of a fair process, they realized that a certain unfairness was an inherent part of the process, and that efforts in creating a fair process would not change the outcome.

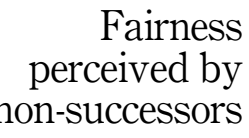

\section{Discussion and conclusions}

The central research question for this study was: How do non-succeeding siblings perceive justice with regard to family firm succession? To answer this question, we utilized a framework based on justice theory to analyze perceptions of fairness among non-succeeding siblings in the context of family farms. The position of non-succeeding siblings is important because sibling relationships have a significant impact on family harmony (Whiteman et al., 2011) and family harmony may influence the long term success of the business (e.g. Sharma, 2004). We choose the family farm context to study this question because it offers the opportunity to analyze the effect on sibling relationships of an unequal outcome. Unequal distribution is a common reality in today's rural economic and social landscape as, because of low farm returns (Glover and Reay, 2015), non-succeeding siblings need to grant the farm to the successor and accept negative consequences for their own wealth in order to make possible the continuity of the farm. The particular situation created by these circumstances is conducive to increasing our understanding of perceived justice.

Maintaining harmony is an important goal for business families and therefore a crucial criterion by which to measure whether succession has been successfully accomplished. The acceptance of the outcome by the non-succeeding siblings is an important resource for sustaining family harmony. Based on the analysis of our interview data and its application to the justice literature, we propose a model to show that the relation between the principles of justice applied by the incumbents and successors and the acceptance of the outcome by the non-succeeding siblings is moderated by how non-successors perceive the fairness of both the process and the outcome.

In small family businesses, parents tend to make decisions during the succession process together with the successor (Le Breton-Miller et al., 2004). Our findings reveal that these decisions are based on various principles of justice, reflecting a combination of how business, family and ownership perspectives influence the succession process. Parents seem to combine merit, gender, needs and equality, and in many cases they are not explicit about how they do this and which criteria they give priority. The non-succeeding siblings are, in most cases, not directly involved in this decision-making process, but they are affected by the consequences of the decisions. Consequently, they reflect from a certain distance on the succession process, evaluate the outcome and try to find a way to deal with it. Like their parents, they combine and weigh the various perspectives of distributive justice and evaluate the outcome of the succession process. Moreover when the non-succeeding siblings apply the same justice perspectives as the incumbents and the successor, it helps in the acceptance of the outcomes.

Merit in the business sphere, needs in the family sphere and equality in the ownership sphere are the main guiding principles for decision-making suggested in the literature (e.g. Van der Heyden et al., 2005). However, our study reveals that the overlap and interdependence among the different spheres require stakeholders to apply specific strategies to cope with this complex context. One strategy that non-succeeding siblings seem to apply is prioritizing different guiding principles. They prioritize the continuity of the family farm; that is, the emotional need to continue the farm seems to outweigh the individual needs of the non-successor.

This finding relates to the "rough family justice" approach suggested by Ayres (1990), who argues that when a family business faces succession issues, the principle of 
equality does not work. Instead, "rough family justice," which he defines as "equity designed to serve the best interests of the family business" (Ayres, 1990, p. 5), is a more realistic goal. Ayres suggests rough family justice as an approach for family business advisors, but our study reveals that non-succeeding siblings seem to apply this approach themselves. What stimulates this focus on business continuity is that it is also the wish of the parents and successors, so that if non-succeeding siblings help to make it possible they also meet the needs of their family members, which is important for them as well. Furthermore, siblings acknowledge the implications of contextual factors, such as being part of a large family, dependence on the land and the likelihood of low returns, and they plan accordingly.

However, this study also reveals that non-succeeding siblings draw boundaries or expect things in return for their willingness to help the successor. For example, siblings are willing to help the successor only if he is very motivated and works hard, and he is not allowed to sell the farm. In many families, the decision-making process is not transparent, and often these expectations and claims by the non-succeeding siblings are not explicit either. Moreover since the timespan of the succession process is long, non-succeeding siblings' perceptions of fairness can change, potentially affecting family harmony and endangering the continuity of the business.

This makes time an important factor. First, in most family farms the selection of the successor takes place when the siblings are young adults. Within a farm family, children trust their parents to make the right decision. However, after some of those children leave the farm and start their own households, they gradually become more attached to their own families. As time passes, this can affect the loyalty they feel toward their parents and siblings. Second, it is important to note that succession often takes place much earlier than inheritance. Although decisions about the distribution of property are made during the succession process, the ultimate financial consequences only become clear when the parents pass away. If the distribution of the inheritance is not openly discussed during the succession process, the non-succeeding siblings may face unexpected financial disappointments later, which can lead to severe conflicts with the successor.

Although procedural justice in general helps promote acceptance of the outcomes of the succession process, we found that stakeholders had mixed feelings about elements of procedural justice. Parents expressed their willingness to involve all children in the decisions surrounding the transfer of the farm. However, at the same time, they are afraid that providing information will make it clear how unequal the distribution of the equity is, and they fear the reaction of the non-successors. Non-successors realize the consequences of continuing the farm and do not see how more information and further discussion will change their situations; consequently, they view procedural justice as less important.

\section{Practical implications}

For farming families and their stakeholders, this study highlights the importance of acknowledging the role of non-succeeding siblings. In general, non-succeeding siblings seem willing to grant the farm to the successor owing to the perceived value of continuing to operate the farm within the family. In other words, they seem to prioritize family needs over other principles of distributive justice. However, our findings also show that an overall positive evaluation of the succession among siblings is the outcome of a complex process that may be influenced by different events. For parents and successors, it is important to realize that non-successors may have different perceptions of justice with regard to merit, gender, needs and equality and that those perceptions may change over time. Matters are made even more difficult by the fact that these perceptions are often not made explicit by non-successors 
during the succession process. In many cases, parents are also not explicit about how they combine and prioritize their own principles of justice. One practical implication in this regard is that communication during the succession process should be aimed at making more explicit the principles of justice being applied by successors, parents and non-successors. Communication skills are indeed valuable resources that can help establish and maintain a fair process that supports the perception of justice. In addition, training programs for successors and their advisors should stress the importance of involving all family members in the succession process. Furthermore, non-succeeding siblings seem to have a lack of knowledge about the technical details of succession. Given that one element of procedural justice is ensuring that everyone involved truly understands the content of the decisions being made, attention should be paid to avoiding a knowledge gap between successors, parents and non-successors.

\section{Limitations and future research}

This study suffers from several limitations. First, the families that participated in this study had a basic awareness that all family members should be involved in the succession process. As such, our findings may be biased toward families with more advanced communication skills. Future research focused on families in which this is not the case would be welcome. Second, our study offers a snapshot, while family farm succession is a long process that takes many years. Future research with a longitudinal approach would be helpful in expanding our understanding of the impact of the lifecycle on perceived justice. We suggest that other researchers should test our framework on a representative sample obtained through a quantitative research method. Moreover, this study sheds some light on the multiple family needs of the parents. Most notable is their goal of fulfilling the family's wish to retain the farm and their willingness to do whatever it takes to accomplish that goal. However, parents also expressed some regrets with regards to their non-succeeding children, and they tried to find ways to compensate for the unequal distribution of property. More research on the multiple family needs of the individual family members and their interactions in the family domain would provide a deeper understanding of the dynamics in business families. Finally, we realized that our findings are influenced by the Dutch context (for instance, its tax and legal system maintain the cultural scripts that accept the unequal outcomes of succession); therefore we recommend more research in different cultures to explore this relationship further. Moreover, studies with different types of business families and in other industries would help in understanding how context influences the application of various distributive justice perspectives. For instance, in families with large businesses with outside directors, the non-succeeding siblings may be more likely to evaluate the outcome of the succession process based on whether they receive an equal share in comparison to the successor.

In conclusion, this paper is one of the few studies in the family business literature to take the role of non-succeeding siblings into account. It shows that non-succeeding siblings have the potential to be an important resource in the achievement of a successful succession. At the same time, their involvement in the family business has a major impact on their personal lives. We hope that this study will motivate other scholars to undertake research in order that we gain a deeper understanding of this specific stakeholder group in family businesses.

\section{References}

Adams, J.S. (1965), "Inequity in social exchange", in Berkowitz, L. (Ed.), Advances in Experimental Social Psychology, Vol. 2, pp. 267-299, Academic Press, New York.

Ayres, G.R. (1990), "Rough family justice: equity in family business succession planning", Family Business Review, Vol. 3 No. 1, pp. 3-22. 
Backus, G.B.C., Baltussen, W.H.M., van Galen, M.A., van der Meulen, H.A.B. and Poppe, K.J. (2009), Voorbij het gezinsbedrijf?: organisatie van het agrarisch bedrijf, nu en in de toekomst, LEI Wageningen UR, Wageningen.

Barach, J.A. and Ganitsky, J.B. (1995), "Successful succession in family business", Family Business Review, Vol. 8 No. 2, pp. 131-155.

Bennedsen, M., Nielsen, K.M., Pérez-González, F. and Wolfenzon, D. (2007), "Inside the family firm: the role of families in succession decisions and performance", Quarterly Journal of Economics, Vol. 122 No. 2, pp. 647-691.

Beukema, (2017), available at: www.boerderij.nl/Home/Achtergrond/2017/11/Gunfactor-bij-overnamebelangrijker-dan-ooit-214132E.

Blanc, M. (1994), "Introduction family farming in a changing world", Sociologia Ruralis, Vol. 34 No. 4, pp. 279-292.

Braaksma, R., Verhoeven, W., Span, L. and Smit, L. (2012), Financieringsmonitor 2012-1, Onderzoek naar de financiering van het Nederlandse bedrijfsleven, Panteia, Zoetermeer.

Byrne, J., Fattoum, S. and Thébaud, S. (2018), "A suitable boy? Gendered roles and hierarchies in family business succession”, European Management Review, Vol. 16 No. 3, pp. 579-596.

Calabrò, A., Minichilli, A., Amore, M.D. and Brogi, M. (2018), "The courage to choose! Primogeniture and leadership succession in family firms", Strategic Management Journal, Vol. 39 No. 7, pp. 2014-2035.

Calus, M. and Van Huylenbroeck, G. (2010), "The persistence of family farming: a review of explanatory socio-economic and historical factors", Journal of Comparative Family Studies, Vol. 41 No. 5, pp. 639-660.

Calus, M. (2009), Factors Explaining Farm Succession and Transfer in Flanders, Ghent University, Belgium.

Carlock, R. and Ward, J. (2001), Strategic Planning for the Family Business: Parallel Planning to Unify the Family and Business, Springer, Boston, MA.

Cassidy, A. and McGrath, B. (2014), "The relationship between 'non-successor' farm offspring and the continuity of the Irish family farm”, Sociologia Ruralis, Vol. 54 No. 4, pp. 399-416.

CBS (2015), "Vergrijzing op boerderijen zet door", available at: https://www.cbs.nl/nl-nl/nieuws/2015/ 47/vergrijzing-op-boerderijen-zet-door.

CBS (2016), "Aantal melkveebedrijven per grootteklasse in de jaren 2000 tot en met 2016 en de provincies", available at: https:/www.cbs.nl/nl-nl/maatwerk/2016/49/aantal-melkveebedrijvenper-grootteklasse-2000-2016-.

Cicirelli, V.G. (1995), "Sibling relationships in cross-cultural perspective", Sibling Relationships across the Life Span, Springer, Boston, MA, pp. 69-85.

Colquitt, J.A., Conlon, D.E., Wesson, M.J., Porter, C.O. and Ng, K.Y. (2001), "Justice at the millennium: a meta-analytic review of 25 years of organizational justice research", Journal of Applied Psychology, Vol. 86 No. 3, p. 425.

Cropanzano, R. and Wright, T.A. (2001), "When a 'happy' worker is really a 'productive' worker: a review and further refinement of the happy-productive worker thesis", Consulting Psychology Journal: Practice and Research, Vol. 53 No. 3, p. 182.

Cropanzano, R., Bowen, D.E. and Gilliland, S.W. (2007), "The management of organizational justice", Academy of Management Perspectives, Vol. 21 No. 4, pp. 34-48.

Daspit, J.J., Holt, D.T., Chrisman, J.J. and Long, R.G. (2016), "Examining family firm succession from a social exchange perspective: a multiphase, multistakeholder review", Family Business Review, Vol. 29 No. 1, pp. 44-64.

De Massis, A. and Kotlar, J. (2014), "The case study method in family business research: guidelines for qualitative scholarship”, Journal of Family Business Strategy, Vol. 5 No. 1, pp. 15-29. 
Dubois, A. and Gadde, L.E. (2002), "Systematic combining: an abductive approach to case research", Journal of Business Research, Vol. 55 No. 7, pp. 553-560.

Dubois, A. and Gadde, L.E. (2014), "Systematic combining'-a decade later", Journal of Business Research, Vol. 67 No. 6, pp. 1277-1284.

Dumas, C., Dupuis, J.P., Richer, F. and Cyr, L. St. (1995), "Factors that influence the next generation's decision to take over the family farm", Family Business Review, Vol. 8 No. 2, pp. 99-120.

Emmel, N. (2013), Sampling and Choosing Cases in Qualitative Research: A Realist Approach, SAGE Publications, Thousand Oaks, CA.

Esterman, K. and Hedlund, D. (1994), "Comparing rural adolescents from farm and nonfarm families", Journal of Research in Rural Education, Vol. 11 No. 2, pp. 84-91.

Eurostat (2013), "Rural development in the EU; statistical and economic information report 2013", available at: https://ec.europa.eu/info/food-farming-fisheries/key-policies/common-agriculturalpolicy/cmef\#indicator.

FAO, (2014) "Family farmers: feeding the world, caring for the earth", available at: http://www.fao.org/ resources/infographics/infographics-details/en/c/230925/.

Farrington, S.M., Venter, E. and Boshoff, C. (2012), "The role of selected team design elements in successful sibling teams", Family Business Review, Vol. 25 No. 2, pp. 191-205.

Festinger, L. (1954), "A theory of social comparison processes", Human Relations, Vol. 7 No. 2, pp. 117-140.

Friedman, S.D. (1991), "Sibling relationships and intergenerational succession in family firms", Family Business Review, Vol. 4 No. 1, pp. 3-20.

Garcia, P.R.J.M., Sharma, P., De Massis, A., Wright, M. and Scholes, L. (2019), "Perceived parental behaviors and next-generation engagement in family firms: a social cognitive perspective", Entrepreneurship: Theory and Practice, Vol. 43 No. 2, pp. 224-243.

Gasson, R. and Errington, A. (1993), The Farm Family Business, CABI, Wallingford.

Gibb Dyer, W. Jr and Sánchez, M. (1998), "Current state of family business theory and practice as reflected in Family Business Review 1988-1997", Family Business Review, Vol. 11 No. 4, pp. 287-295.

Gilding, M., Gregory, S. and Cosson, B. (2015), "Motives and outcomes in family business succession planning", Entrepreneurship: Theory and Practice, Vol. 39 No. 2, pp. 299-312.

Glover, J.L. and Reay, T. (2015), "Sustaining the family business with minimal financial rewards: how do family farms continue?", Family Business Review, Vol. 28 No. 2, pp. 163-177.

Goldman, B. and Cropanzano, R. (2015), “Justice' and 'fairness' are not the same thing”, Journal of Organizational Behavior, Vol. 36 No. 2, pp. 313-318.

Harvey, M. and Evans, R.E. (1994), "Family business and multiple levels of conflict", Family Business Review, Vol. 7 No. 4, pp. 331-348.

Heath, S. (2018), "Siblings, fairness and parental support for housing in the UK", Housing Studies, Vol. 33 No. 2, pp. 284-298.

Ingersoll-Dayton, B., Neal, M.B., Ha, J.H. and Hammer, L.B. (2003), "Redressing inequity in parent care among siblings", Journal of Marriage and Family, Vol. 65 No. 1, pp. 201-212.

Jaskiewicz, P. and Dyer, W.G. (2017), "Addressing the elephant in the room: disentangling family heterogeneity to advance family business research", Family Business Review, Vol. 30, pp. 111-118.

Jennings, J.E., Breitkreuz, R.S. and James, A.E. (2013), "When family members are also business owners: is entrepreneurship good for families?”, Family Relations, Vol. 62 No. 3, pp. 472-489.

Keating, N.C. and Little, H.M. (1997), "Choosing the successor in New Zealand family farms", Family Business Review, Vol. 10 No. 2, pp. 157-171. 
Kelley, H.H. and Thibaut, J.W. (1978), Interpersonal Relations: A Theory of Interdependence, Wiley, New York, NY.

Kidwell, R.E., Eddleston, K.A., Cater, J.J. III and Kellermanns, F.W. (2013), "How one bad family member can undermine a family firm: preventing the Fredo effect”, Business Horizons, Vol. 56 No. 1 , pp. 5-12.

Kim, W.C. and Mauborgne, R.A. (1993), "Procedural justice, attitudes, and subsidiary top management compliance with multinationals' corporate strategic decisions", Academy of Management Journal, Vol. 36 No. 3, pp. 502-526.

Kissling, S., Bird, M. and Zellweger, T.M. (2017), "Who gets what? Justice principles in family business succession", Academy of Management Proceedings, Academy of Management, Briarcliff Manor, NY 10510, Vol. 2017 No. 1, p. 16824.

KPMG (2018), "Global family business tax monitor", available at: https://home.kpmg.com/ie/en/home/ insights/2018/05/global-family-business-tax-monitor.html.

Langley, A. and Abdallah, C. (2011), "Templates and turns in qualitative studies of strategy and management", Building Methodological Bridges, Emerald Group Publishing Limited, Bingley.

Le Breton-Miller, I., Miller, I. and Steier, L.P. (2004), "Toward an integrative model of effective FOB succession”, Entrepreneurship: Theory and Practice, Vol. 28 No. 4, pp. 305-328.

Lerner, M.J. (1980), The Belief in a Just World: A Fundamental Delusion, Plenum, New York.

Leventhal, G.S. (1980), "What should be done with equity theory? New approaches to the study of fairness in social relationships", in Gergen, K., Greenberg, M. and Willis, R. (Eds), Social Exchange: Advances in Theory and Research, Plenum Press, New York, pp. 27-55.

Litz, R.A., Pearson, A.W. and Litchfield, S. (2012), "Charting the future of family business research: perspectives from the field", Family Business Review, Vol. 25 No. 1, pp. 16-32.

Litz, R.A. (2008), "Two sides of a one-sided phenomenon: conceptualizing the family business and business family as a möbius strip”, Family Business Review, Vol. 21 No. 3, pp. 217-236.

MacQueen, K.M., McLellan-Lemal, E., Bartholow, K. and Milstein, B. (2008), "Team-based codebook development: structure, process, and agreement", in Guest, G. and MacQueen, K.M. (Eds), Handbook for Team-Based Qualitative Research, AltaMira Press, Lanham, MD, pp. 119-135.

Matser, I.A. and Slager, J. (2017), "De boerderij als erfstuk", in De Beer, P., Van der Meer, J. and Van Gennep (Eds), Voor wie is de erfenis? Over vrijheid, gelijkheid en familiegevoel.

Pérez Rodríguez, M.J. and Basco, R. (2011), "The cognitive legitimacy of the family business field", Family Business Review, Vol. 24 No. 4, pp. 322-342.

Quinn, C.E. and Halfacre, A.C. (2014), "Place matters: an investigation of farmers' attachment to their land", Human Ecology Review, pp. 117-132.

Rawls, J. (1971), A Theory of Justice, Harvard University Press, Cambridge, MA.

Richards, M., Kammerlander, N. and Zellweger, T. (2019), "Listening to the heart or the head? Exploring the 'willingness versus ability' succession dilemma”, Family Business Review, Vol. 32 No. 4, pp 330-353.

Samara, G. and Paul, K. (2019), "Justice versus fairness in the family business workplace: a socioemotional wealth approach", Business Ethics: A European Review, Vol. 28 No. 2, pp. 175-184.

Sharma, P. and Irving, P.G. (2005), "Four bases of family business successor commitment: antecedents and consequences", Entrepreneurship: Theory and Practice, Vol. 29 No. 1, pp. 13-33.

Sharma, P. (2004), "An overview of the field of family business studies: current status and directions for the future", Family Business Review, Vol. 17 No. 1, pp. 1-36.

Stokkers, R., van der Meer, R.W., Schoorlemmer, H.B. and Hendriks-Goossens, V.J.C. (2010), Opvolgers gezocht voor het boerenbedrijf (No. 2010-042), LEI Wageningen UR, Wageningen. 
Strawbridge, W.J. and Wallhagen, M.I. (1991), "Impact of family conflict on adult child caregivers", The Gerontologist, Vol. 31 No. 6, pp. 770-777.

Suess-Reyes, J. and Fuetsch, E. (2016), "The future of family farming: a literature review on innovative, sustainable and succession-oriented strategies", Journal of Rural Studies, Vol. 47 No. Part A, pp. 117-140.

Tagiuri, R. and Davis, J. (1996), "Bivalent attributes of the family firm”, Family Business Review, Vol. 9 No. 2, pp. 199-208.

Taylor, J.E. and Norris, J.E. (2000), "Sibling relationships, fairness, and conflict over transfer of the farm”, Family Relations, Vol. 49 No. 3, pp. 277-283.

Thibaut, J.W. and Walker, L. (1975), Procedural Justice: A Psychological Analysis, Erlbaum, Hillsdale, NJ.

Thomson, N.R. and Jones, E.F. (2005), “Children's, adolescents', and young adults' reward allocations to hypothetical siblings and fairness judgments: effects of actor gender, character type, and allocation pattern", Journal of Psychology, Vol. 139 No. 4, pp. 349-368.

Van der Heyden, L., Blondel, C. and Carlock, R.S. (2005), "Fair process: striving for justice in family business", Family Business Review, Vol. 18 No. 1, pp. 1-21.

Van der Meulen, H.A.B., Matser, I., Remery, C., Terluin, I.J., Bouma, J. and Jager, J.H. (2014), Vrouwen op agrarische bedrijven: actief en betrokken (No. 14-095), LEI Wageningen UR, Wageningen.

Van der Meulen, H.A.B., Terluin, I.J. and Matser, I.A. (2015), "The role of women on Dutch farms", 20th International Farm Management Congress, Laval University, Québec City, Québec, pp. $450-457$.

Van Maanen, J., Sørensen, J.B. and Mitchell, T.R. (2007), "The interplay between theory and method", Academy of Management Review, Vol. 32 No. 4, pp. 1145-1154.

Wallace, C., Dunkerley, D., Cheal, B. and Warren, M. (1994), "Young people and the division of labour in farming families", Sociological Review, Vol. 42 No. 3, pp. 501-530.

Ward, J.L. (1987), Keeping the Family Business healthy: How to Plan for Continuing Growth, Profitability, and Family Leadership, Jossey-Bass, San Francisco.

Whiteman, S.D., McHale, S.M. and Soli, A. (2011), "Theoretical perspectives on sibling relationships", Journal of Family Theory and Review, Vol. 3 No. 2, pp. 124-139.

Wiley, A.R., Bogg, T. and Ringo Ho, M.H. (2005), "The influence of parental socialization factors on family farming plans of preadolescent children: an exploratory analysis", Journal of Research in Rural Education, Vol. 20 No. 11, pp. 1-12.

Yu, A., Lumpkin, G.T., Sorenson, R.L. and Brigham, K.H. (2012), "The landscape of family business outcomes: a summary and numerical taxonomy of dependent variables", Family Business Review, Vol. 25 No. 1, pp. 33-57.

Zellweger, T.M., Nason, R.S. and Nordqvist, M. (2012), "From longevity of firms to transgenerational entrepreneurship of families: introducing family entrepreneurial orientation", Family Business Review, Vol. 25 No. 2, pp. 136-155.

\section{Appendix \\ Topic list for interviews with non-succeeding siblings}

A. Family context

(1) Current family context: The positions of family members in the business.

(2) Decision-making at the operational and strategic levels: Current versus ideal situations.

(3) Relationships among family members: Examples of close family ties.

(4) Career choice: Consideration of becoming a farmer in the past. Reasons for not becoming a farmer. 
(5) Assistance with farm work in the past: Expectations of parents.

(6) Influence of farming background on choice of current education or career.

B. History of the farm as a family business

(1) History of the family business.

(2) Founding of the family business (time and place).

(3) Number of generations in the family business.

C. The business situation (mission, vision and strategy)

(1) Competitive advantage of the farm (e.g. feed costs, breeding and cultivation techniques).

(2) Farm-related opportunities and threats (e.g. legislation, environment and profit).

(3) Personal objectives for the next 10 years.

\section{Succession process and meetings}

(1) Discussion of (sensitive) topics during succession process and satisfaction with that process.

(2) Challenges and frustrations during the succession process.

(3) Perceived importance of different opinions and involvement during the succession process.

(4) Procedure and timing of succession meetings (e.g. initiation, information transfer, equality of discussion partners, reflection on meetings and satisfaction with process and outcomes).

(5) Personal consequences of farm succession (e.g. practical, financial and legal).

(6) Actual succession process versus ideal succession process.

(7) Alternative options in the succession process (e.g. people and other business options).

(8) Desired characteristics, motivations and traits for a potential successor versus current successor.

(9) Parents' preferences for a certain successor.

E. The "granting factor"

(1) Fairness of the succession process.

(2) Importance and examples of "granting" with regard to succession.

(3) Importance of continuing the farm as a family business.

(4) Advantages for non-successors if the farm remains in the family.

(5) Potential influence on decision-making as a non-successor.

(6) Desires as a non-successor with regard to succession.

\section{Corresponding author}

Ilse Matser can be contacted at: ia.matser@windesheim.nl

For instructions on how to order reprints of this article, please visit our website:

www.emeraldgrouppublishing.com/licensing/reprints.htm

Or contact us for further details: permissions@emeraldinsight.com 